\title{
Evaluation of the thermal performance of different cold materials for urban paving
}

\section{(Avaliação do desempenho térmico de diferentes materiais frios para pavimentação urbana)}

\author{
L. C. Castro, K. M. Degues, M. G. Cypriano, M. R. Rocha, O. R. K. Montedo, E. Angioletto* \\ Programa de Pós-Graduação em Ciência e Engenharia de Materiais, Universidade do Extremo Sul Catarinense, \\ Av. Universitária, 1105, P.O. Box 3167, Criciúma, SC, Brazil 88806-000 \\ castro@unesc.net,kanandamd@hotmail.com,mateus_cypriano@hotmail.com,marcio2r@gmail.com, \\ oscar.rkm@gmail.com,*ean@unesc.net
}

\begin{abstract}
The phenomenon of the warming of cities at high temperature levels, the so-called "heat island", has been studied around the world. Apart from generating thermal discomfort, this urban phenomenon has been causing an increase in the demand for energy for cooling the environments. In response to the environmental impact generated by this phenomenon, researchers from different nations have developed techniques for warming mitigation, developing new materials, technologies, and constructive systems. In this context, urban paving is responsible for a significant contribution to the occurrence of heat islands in cities. The use of pavements called "cold materials", which help to lower the surface temperature, constitutes an important solution to mitigate the effects of the heat flow in cities and the planet. Thus, the purpose of this study was to develop, test and evaluate new cold materials for use in paving. Such cold materials proved to present better thermal performance than conventional ones, such as asphalt and reference concrete (commercial paver). In fact, this work showed that the composition with $90 \%$ concrete $+10 \%$ talc can be considered cold material, with energy savings of up to $16 \%$ in comparison to asphalt.
\end{abstract}

Keywords: cold materials, thermal performance, heat islands, reflection, emissivity.

\section{Resumo}

O fenômeno do aquecimento das cidades a patamares de temperatura elevados, as chamadas "ilhas de calor", vem sendo estudado no mundo todo. Além de gerar desconforto térmico urbano, provocam maior demanda de energia para refrigerar os ambientes. Em resposta ao impacto ambiental gerado por esse fenômeno, pesquisadores de diferentes nações vêm desenvolvendo técnicas para atenuação do aquecimento, desenvolvendo novos materiais, tecnologias e sistemas construtivos para os elementos construidos do espaço urbano. Neste sentido, a pavimentação urbana é responsável por significativa contribuição para a ocorrência das ilhas de calor nas cidades. A utilização de pavimentos chamados "frios" apresenta menor temperatura superficial e constitui-se numa solução importante para mitigar os efeitos do fluxo de calor sensivel nas cidades e no planeta. Diante desse panorama, o propósito desse trabalho foi desenvolver, testar e avaliar novos materiais frios para uso em pavimentação. Tais materiais frios provaram apresentar melhor desempenho térmico que aqueles materiais convencionais, tais como asfalto e concreto de referência (paver comercial). De fato, este trabalho mostrou que a composição com $90 \%$ concreto $+10 \%$ talco pode ser considerada material frio, com economia de energia de até $16 \%$ em comparação com asfalto.

Palavras-chave: materiais frios, desempenho térmico, ilhas de calor, reflexão, emissividade.

\section{INTRODUCTION}

Cities occupy approximately $2 \%$ of the Earth's surface, and their inhabitants consume $75 \%$ of world energy resources. Under certain conditions, the heat of solar radiation in different urban activities can raise temperatures in some areas, simply because of the way a city is structured. These effects are known as urban heat islands (UHI) [1]. Buchin et al. [2] reported a monitoring of the internal temperatures inside buildings in Germany that are inhabited by over 65 years old individuals, and the results showed that the risk to health increases progressively with increasing temperature and approximately double with every $1 \mathrm{~K}$ increase in environment temperature. They used four building models to fit their experimental data named EnergyPlus, Linear, Physical and Recursive. Quantitative risk analysis was evaluated. The hazard was calculated with threshold temperatures in the range of 16 to $30{ }^{\circ} \mathrm{C}$ for outdoor air temperatures and 21 to $33{ }^{\circ} \mathrm{C}$ for indoor temperatures. The daily mortality rates increased from $1.3 \times 10^{-4}$ to $1.6 \times 10^{-4}$ for the indoor temperature increasing from 30 to $32{ }^{\circ} \mathrm{C}$. Buchin et al. [3] have found that the median mortality increased as well for high indoor temperatures $\left(>28^{\circ} \mathrm{C}\right)$.

Yang et al. [4] found that reflective materials are becoming 
an increasingly popular option in urban planning, mitigating the UHI effect and its environmental impacts, especially those involving large-scale urban-atmosphere interactions, which are not clearly understood. Gago et al. [5] established as urban planning strategies, contemplating the increase of green spaces, increasing the albedo of the buildings, and greater concern for pavement surfaces. Dimoudi et al. [6], in their study in Greece, found that the materials used in street paving, sidewalks and urban spaces, and the surfaces of buildings [external vertical seals (facades) and horizontal (flat roofs)] are the "skin" of a city. These materials play a decisive role in the heat transfer processes that takes place between the city and the environment. Materials influence the absorption of solar radiation, the emission of thermal radiation in heat storage, and the evaporation processes that occur in virtually the entire surface of the city.

The effect of the "heat island" has been documented in hundreds of cities worldwide. Studies on the subject provide a complete picture of the problem and a deep understanding of its characteristics [1,7]. Heat islands occur because the materials that make up buildings and pavements in urban areas absorb solar radiation in all frequency bands, including those in the infrared, which in turn heats the materials, storing heat and then dissipating it to the urban environment in the form of long waves [8]. Santamouris [8] suggested improving the thermal performance of pavement to promote an effective mitigation of urban heat and heat islands. The urban envelope plays an important role in heat gains and overheating of cities according to [9]. Taking into account these reported works and the idea of sustainability, this study aimed to evaluate the thermal performance of different materials for urban paving to reduce the UHI, thereby providing energy savings and increasing quality of life.

\section{MATERIALS AND METHODS}

Some guidelines and conceptual strategies were established for this work, where the main premise was to contribute to reducing energy costs and the use of natural resources. Among the materials used in the construction of cities, the pavement used on sidewalks and streets represents a large proportion. Thus, those constructive materials made of cold materials were chosen to be developed in this work. The experiments were divided into two steps, as seen in Fig. 1. The first step was to test materials typically used in urban flooring, while the second step involved the use of new materials developed for comparison. Asphalt, commercial

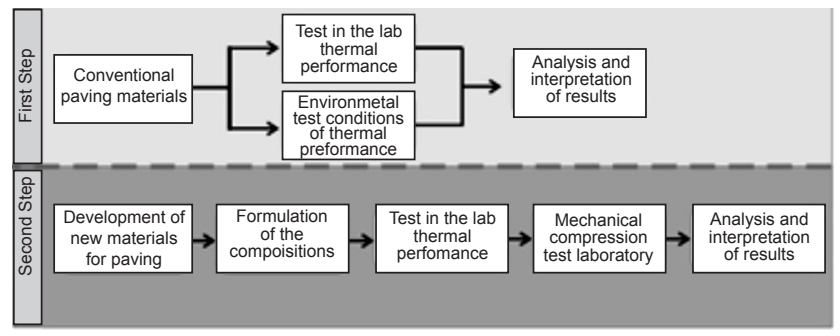

Figure 1: Schematic diagram of the steps of the work development. [Figura 1: Diagrama esquemático das etapas de desenvolvimento do trabalho.]

paver (reference concrete), granite, and tile were used to obtain initial data of the thermal performance. São Tomé stone was also used, since this material is used in external paving due to its good thermal performance and is usually used in paving pool edges and garden sidewalks. São Tomé stone is quartzite and has high contents of micaceous minerals (quartzite São Tomé) that may have very welldeveloped foliation due to the preferential phyllosilicates disposal.

After the tests conducted on conventional materials, concrete (commercial paver) as reference material was chosen as the industrial material to be prepared, developed, and improved. For the new materials, the compositions given in Table I were formulated. The composition of the commercial paver (reference concrete) was determined to meet the requirements of Brazilian standard ABNT NBR 9781:2013 - Concrete paving parts: compressive strength test [10]. The reference concrete was composed by $16 \mathrm{wt} \%$ of cement CP V-ARI (Itambé, Brazil), $41 \mathrm{wt} \%$ of standard sand (fine aggregate, zone 3 according to ABNT NBR $7211: 2005$ [11]), $25 \mathrm{wt} \%$ of crushed stone (coarse aggregate, zone 4.75/12.5 according to ABNT NBR 7211:2005 [11]) and $8 \mathrm{wt} \%$ of water. Cement CP V-ARI is a high early strength Portland cement ( $>27 \mathrm{MPa}$ ) and resistant to sulfates which shows high reactivity at low ages due to high degree of grinding that is submitted. For the obtainment of the reference concrete (commercial paver), the mix design was not changed. Talc and mica were milled and sieved (32 mesh) to produce powders $(<0.5 \mathrm{~mm})$.

Talc and mica were chosen to be used in the composition of the new materials. Talc, because of its thermal properties, is widely used in the industry of insulating ceramics, where the presence of magnesium oxide $(\mathrm{MgO})$ controls the thermal expansion, increasing the resistance to thermal shock, according to [12]. Mica is a generic term applied

Table I - Composition (wt \%) of the new materials.

[Tabela I - Composição (\% em massa) dos novos materiais.]

\begin{tabular}{ccccccc}
\hline \multirow{2}{*}{ Composition } & \multirow{2}{*}{ Talc } & \multirow{2}{*}{ Mica } & Cement & Sand & Crushed stone & Water \\
\hline Commercial paver & 0 & 0 & 17.8 & 45.5 & 27.8 & 8.9 \\
A & 10 & 0 & 16 & 41 & 25 & 8 \\
B & 0 & 10 & 16 & 41 & 25 & 8 \\
\hline
\end{tabular}



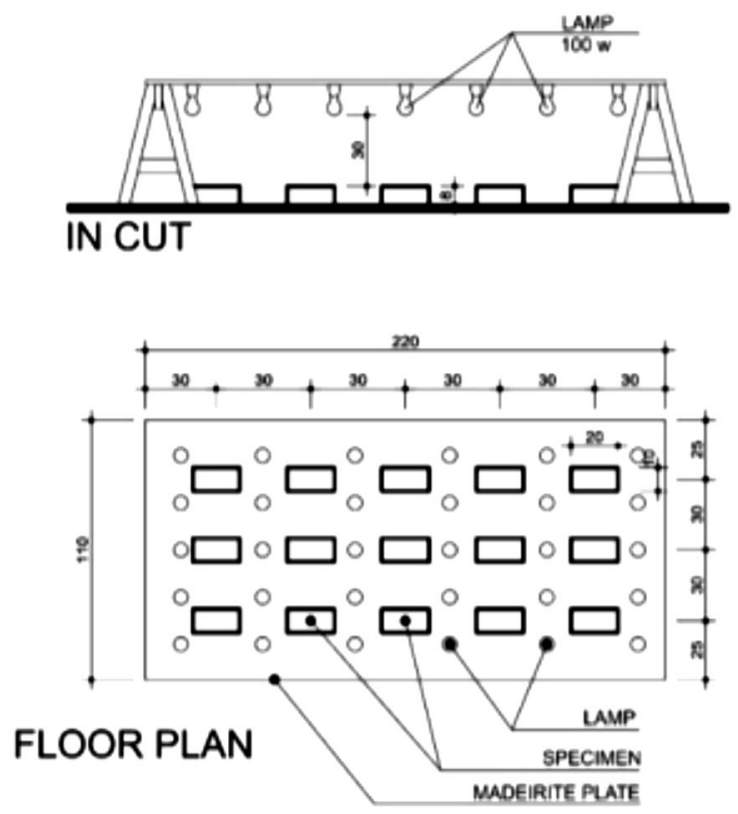

Figure 2: Schematic diagram of the developed device for measuring the effects of artificial radiation.

[Figura 2: Diagrama esquemático do aparato desenvolvido para medida dos efeitos da radiação artificial.]

to a group of minerals consisting of hydrous silicates of aluminum, potassium, sodium, iron and magnesium, which presents good physical properties, such as low thermal conductivity and high resistance to thermal shock. Mica was used in this study because it is one of the constituents of São Tomé stone, a natural material that shows excellent thermal performance [13]. In addition, the use of raw materials, such as talc and mica, is justified because they are cheap minerals that are available in abundance in Brazil and they make up part of the constitution of excellent cementitious aggregates in the construction industry. The use of an aggregate added to the new material instead a surface ink is because of the necessity of frequent maintenance of the latter.

Specimens were prepared from different materials, mentioned previously, in dimensions of $200 \mathrm{~mm}$ x 100 $\mathrm{mm} \times 80 \mathrm{~mm}$. Samples in triplicate were homogeneous in size and composition. In the laboratory, these specimens were subjected to radiation of artificial light and were then left in the open environment, where they were exposed to solar radiation. In the experiment that used artificial light, a device was developed containing 35 incandescent lamps with $100 \mathrm{~W}$ tungsten filaments, as shown in Fig. 2. The manner of distribution of the lamps allowed the incidence of light of the same intensity on all of the bodies submitted to exposure for 15 min with measurements at 3 min intervals. This exposure time was adopted based on previous studies that demonstrated that 15 min was sufficient to significantly change the temperature of the samples with radiation. For $6 \mathrm{~h}$ exposure in natural light with measurement intervals of $2 \mathrm{~h}$, the specimens were randomly distributed in the assembly on a sunny day.
A thermal imager (FLIR) was used to measure the surface temperatures. Additionally, a data-logger with thermocouples was also used to collect the data of the surface temperature as a function of time. The temperature was measured during exposure to incident radiation on the test specimens at different time intervals. The main evaluated parameter was the emissivity in the infrared range, which was measured using one of the functions of the thermal imager (FLIR). These temperature values also served to establish guidelines and information for the development of materials with new compositions to provide superior thermal performance to those presented by conventional materials. For the characterization of the materials, X-ray diffraction (XRD) analyses were performed on the reference concrete (commercial paver), São Tomé stone, and compositions A (concrete+talc) and B (concrete+mica) to determine the mineralogical phases and the types of chemical bonds present. The XRD patterns were obtained with the Shimadzu XRD-6000 (CuKa radiation, $30 \mathrm{~mA}, 30 \mathrm{kV})$; the phases were identified by comparison of measured profile with the diffraction pattern set of the Joint Committee on Powder Diffraction Standards (JCPDS). Compression tests were also performed to verify whether the developed materials had mechanical characteristics suitable for use in flooring. An EMIC PC200 universal machine with Trd30 load cell and speed of $370 \mathrm{kPa} / \mathrm{s}$ were used, as established by the Brazilian standard ABNT NBR 9781/13 [10]. The energy savings obtained by the use of the investigated materials were evaluated in comparison to asphalt by using the heat emitted by radiation of the surfaces, according to [14]:

$$
\begin{aligned}
& \text { Energy saving }=\frac{\left(\mathrm{Q}_{\text {rad }}\right)_{\text {asphalt }}-\left(\mathrm{Q}_{\text {rad }}\right)_{\text {new mat }}}{\left(\mathrm{Q}_{\text {rad }}\right)_{\text {asphalt }}} \\
& \mathrm{Q}_{\mathrm{rad}}=\sigma \mathrm{AT}^{4}
\end{aligned}
$$

where, $\sigma$ is the Stefan-Boltzmann constant $\left(5.67 \times 10^{-8} \mathrm{~W} / \mathrm{m}^{2} \mathrm{~K}^{4}\right)$, A is the heat exchange surface $\left(\mathrm{m}^{2}\right)$ and $\mathrm{T}$ is the absolute surface temperature (K). Surface temperatures of the different materials and the reference (asphalt) exposed to solar radiation were measured by using a thermographic camera. The maximum measured temperatures were considered. The maximum time of exposure was $6 \mathrm{~h}$ a day.

\section{RESULTS AND DISCUSSION}

Thermal performance: Figs. 3 and 4 show the thermal behavior of the materials usually used as paving (first step of the procedure, Fig. 1). Fig. 3 shows the development of the test for verifying the thermal performance of the samples after 6 $\mathrm{h}$ of exposure to direct sunlight. In Fig. 3b, the thermographic imaging shows that the asphalt samples reached the highest temperatures and São Tomé stone samples showed the lowest temperature, as shown in the color gradient image from the thermographic camera. Fig. 4 shows the results of the temperatures obtained with the thermal imager for the 
exposure of the specimens to artificial light and sunlight, respectively. As seen in Fig. 4a, the materials that had the best performance under exposure to artificial light in 15 min periods were granite and stone, reaching 36.4 and 36.9 ${ }^{\circ} \mathrm{C}$, respectively. The material with the worst performance during testing with artificial light was asphalt, reaching 40.6 ${ }^{\circ} \mathrm{C}$. Thus, the gap presented between granite and asphalt (lower and higher temperature) was $4.2^{\circ} \mathrm{C}$. This difference in temperature between the materials in the urban space was significant because it causes an environmental impact on micro and mesoclimate cities. Fig. $4 \mathrm{~b}$ shows that the material with the best performance in sunlight was the São Tomé stone, reaching $47.4{ }^{\circ} \mathrm{C}$. The worst performance was achieved by asphalt, reaching $59.8^{\circ} \mathrm{C}$. Thus, the difference between the materials in sunlight conditions was even more evident at $12.4{ }^{\circ} \mathrm{C}$. The temperature drop in a time interval between 11 and $12 \mathrm{~h}$ was due to the concealment of sunlight by clouds during the experiment.
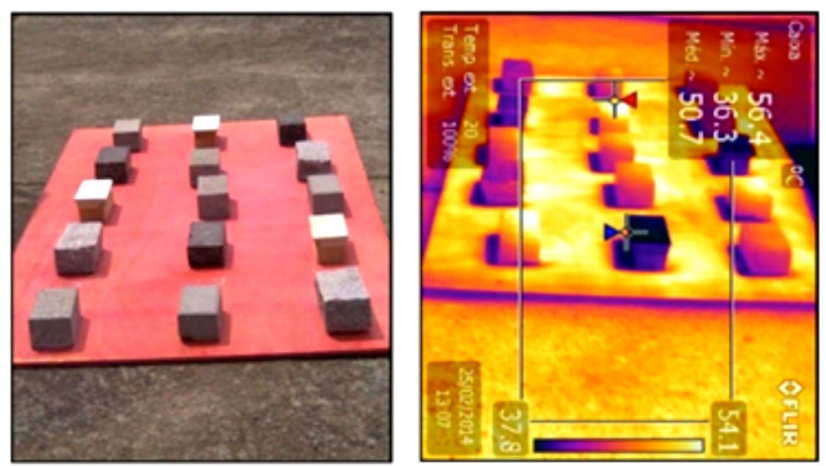

Figure 3: Exposure of samples to sunlight (a), and appearance of the samples observed in the thermal image during exposure (b).

[Figura 3: Exposição das amostras à luz solar (a) e aparência das amostras observadas na imagem térmica durante a exposição (b).]

In the second stage of the study, the thermal performance presented by the developed materials was compared with some previously tested materials: asphalt (reference), paver (reference concrete) and São Tomé stone. Fig. 5 shows the results obtained with a thermographic camera for materials heated using artificial light and sunlight, respectively. Fig. 5a shows the typical curves of materials under heating.
From $30 \mathrm{~min}$, the tested materials underwent a thermal stability process, where the temperature differences remained constants. The best performing materials were A (concrete+talc) and São Tomé stone, reaching temperatures of 40.5 and $39{ }^{\circ} \mathrm{C}$, respectively. The worst performing material was asphalt, which reached $47.1{ }^{\circ} \mathrm{C}$. Thus, the difference between the evaluated materials with the best and worst performers in artificial light was $8.1^{\circ} \mathrm{C}$. According to Fig. $5 \mathrm{~b}$, the materials that showed the best performance when exposed to sunlight were the São Tomé stone and material A (concrete+talc), reaching temperatures of 37 and $37.5^{\circ} \mathrm{C}$, respectively, and again, the material with the worst performance was asphalt, reaching $49.8^{\circ} \mathrm{C}$. Thus, the difference between the materials with the best and worst performance was $12.8^{\circ} \mathrm{C}$.

However, there was a difference in the temperature measurement for the methods of artificial light and sunlight. For São Tomé stone, temperatures of 39 and $37{ }^{\circ} \mathrm{C}$ were obtained (difference of $2{ }^{\circ} \mathrm{C}$ ), whereas for material A (concrete+talc), the temperatures were 40.5 and $37.5{ }^{\circ} \mathrm{C}$ (difference of $3{ }^{\circ} \mathrm{C}$ ). The largest difference was obtained for asphalt, with 47.1 and $49.8{ }^{\circ} \mathrm{C}$. Such differences were justified by the difference in the methods employed, including the exposure time of the samples to sunlight and artificial radiation. The measurement methods have many variables and many authors indicate difficulty in the reproducibility of results [15]. To remedy this problem, various measures were conducted, and the observed behavior was similar to that presented by modifying the absolute values of day, wind, and season. However, taking into account the main variable tested in this work (use of mica and talc to obtain cold materials), one can say that, according to Fig. 5, composition A showed better thermal performance than those materials usually used as paving, especially asphalt and commercial paver (reference concrete). Because of this, energy savings and thermal comfort in indoor buildings is to be achieved, in accordance to another researches $[2,3,8]$. In fact, data of emissivity and energy savings confirmed that.

Emissivity: the emissivity of the samples was measured using a thermographic camera. The results are shown in Table II. The bodies with lower values of emissivity
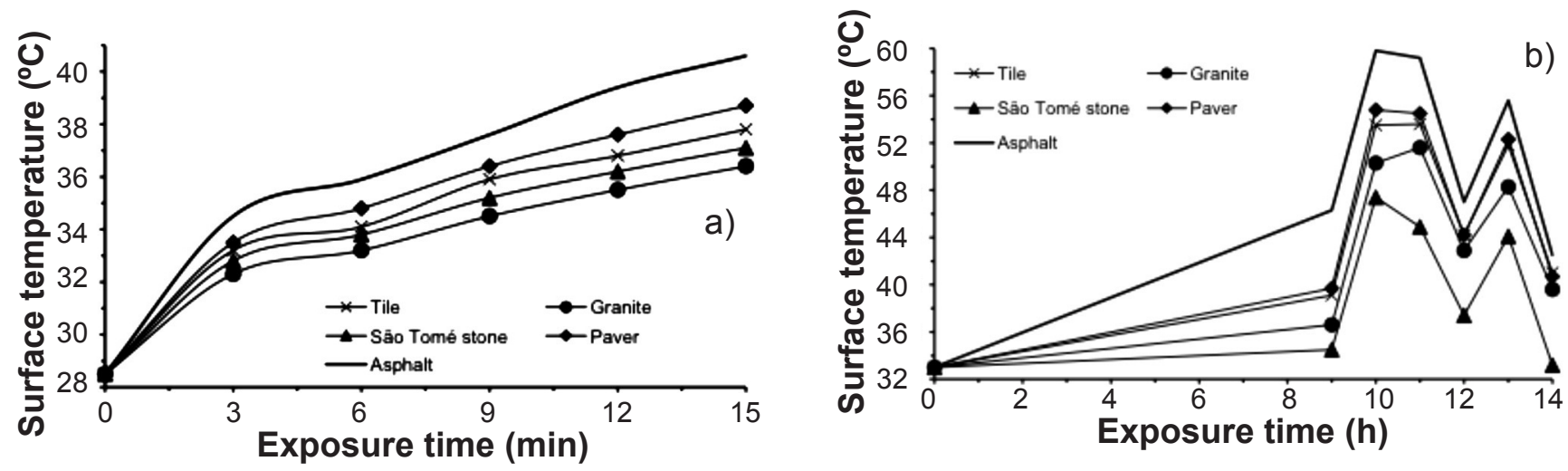

Figure 4: Surface temperature of materials: (a) tested in artificial light; (b) exposed to sunlight.

[Figura 4: Temperatura da superfície de materiais: (a) testados em luz artificial; (b) expostos à luz solar.] 

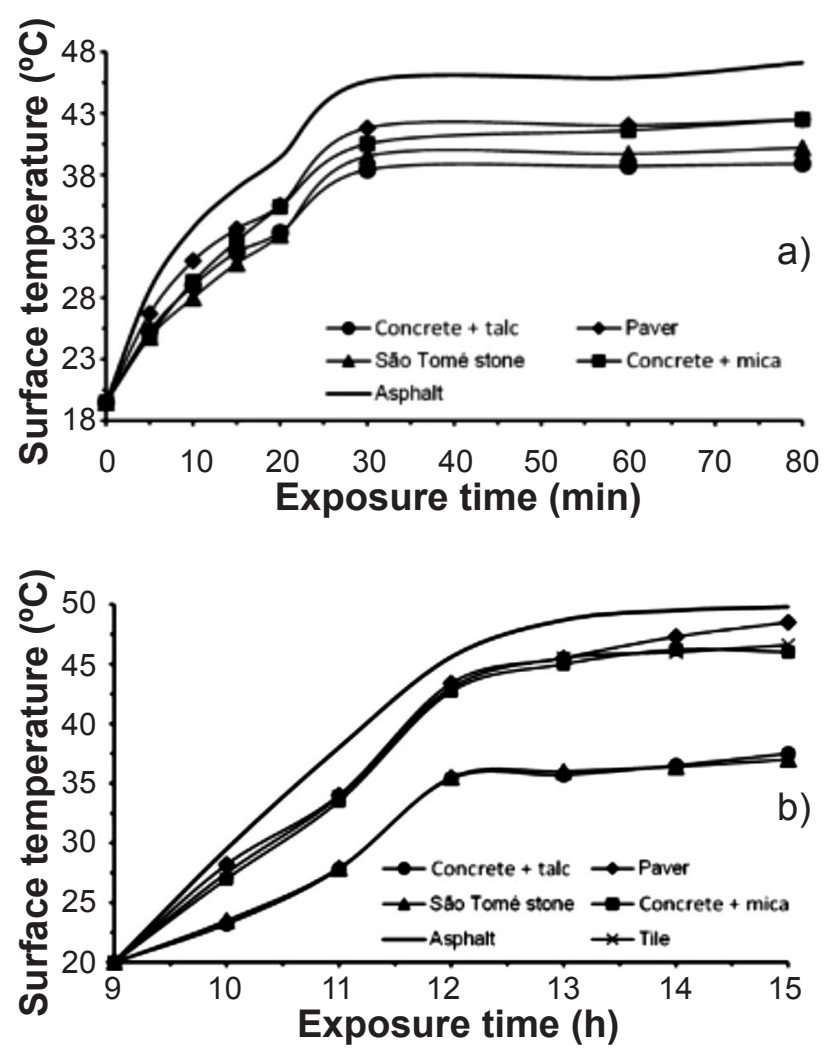

Figure 5: Surface temperature of samples exposed to: (a) artificial radiation; (b) solar radiation.

[Figura 5: Temperatura da superficie de amostras expostas a: (a) radiação artificial; (b) radiação solar.]

(concrete+talc, São Tomé stone and granite) also have the best thermal performances (lower temperatures), as noted in the graphic representations of the temperature, Figs. 4 and 5. Considering only the emissivity, such materials showed good thermal properties for use as urban paving. The use of materials with lower emissivity contributes to making new materials with thermal properties to achieve higher albedo for cities. For [13], emissivity is a measure of how much the surface approaches a black body, for which emissivity is equal to one. Thus, taking account the aim of this work, among the materials listed in Table II, material A (concrete+talc) showed the best performance (lowest emissivity).

Analysis of the crystal structures: Fig. 6 shows the XRD patterns of the studied materials. Reference concrete showed the presence of two crystalline phases: quartz $\left(\mathrm{SiO}_{2}\right.$, JCPDS 46-1045) and calcium hydroxide $\left[\mathrm{Ca}(\mathrm{OH})_{2}\right.$, JCPDS 04-0733]. Composition A (concrete + talc) contained three crystalline phases: quartz ( $\left.\mathrm{SiO}_{2}, \mathrm{JCPDS} 46-1045\right)$, hydrated calcium silicate $\left(\mathrm{Ca}_{1.5} \mathrm{SiO}_{3.5} \mathrm{X} . \mathrm{H}_{2} \mathrm{O}\right.$, JCPDS 33-0306), and magnesium silicate hydroxide (talc, $\mathrm{Mg}_{3} \mathrm{Si}_{4} \mathrm{O}_{10}(\mathrm{OH})_{2}$, JCPDS 29-1493). Composition B (concrete+mica) showed the presence of the crystalline phases quartz $\left(\mathrm{SiO}_{2}, \mathrm{JCPDS}\right.$ 46-1045) and calcium carbonate $\left(\mathrm{CaCO}_{3}\right.$, JCPDS 5-0586). Mica (XRD pattern "d") had two crystalline phases: iron oxide (hematite, $\mathrm{Fe}_{2} \mathrm{O}_{3}$, JCPDS 33-0664) and biotite. In the XRD pattern "e" (talc), the crystalline phases of magnesium
Table II - Emissivity data of the specimens.

[Tabela II - Dados de emissividade das amostras.]

\begin{tabular}{cc}
\hline Material & Emissivity \\
\hline Black background & 0.95 \\
Asphalt & 0.94 \\
Reference concrete & 0.90 \\
Concrete + talc & 0.49 \\
Concrete + mica & 0.79 \\
São Tomé stone & 0.62 \\
Granite & 0.71 \\
\hline
\end{tabular}

silicate hydroxide (talc, $\mathrm{Mg}_{3} \mathrm{Si}_{4} \mathrm{O}_{10}(\mathrm{OH})_{2}$, JCPDS 29-1493) and quartz $\left(\mathrm{SiO}_{2}, \mathrm{JCPDS} 46-1045\right)$ are observed. The crystalline phases present in the concrete are typically found in this kind of material. The addition of talc to the concrete (composition A) resulted in a whiter material; therefore, the emissivity decreased significantly (Table II), which resulted in different thermal behavior and better performance. On the other hand, no significant change in emissivity occurred for the addition of mica because of the presence of hematite, which has a reddish color; moreover, the presence of dark colored biotite maintained the high emissivity index.

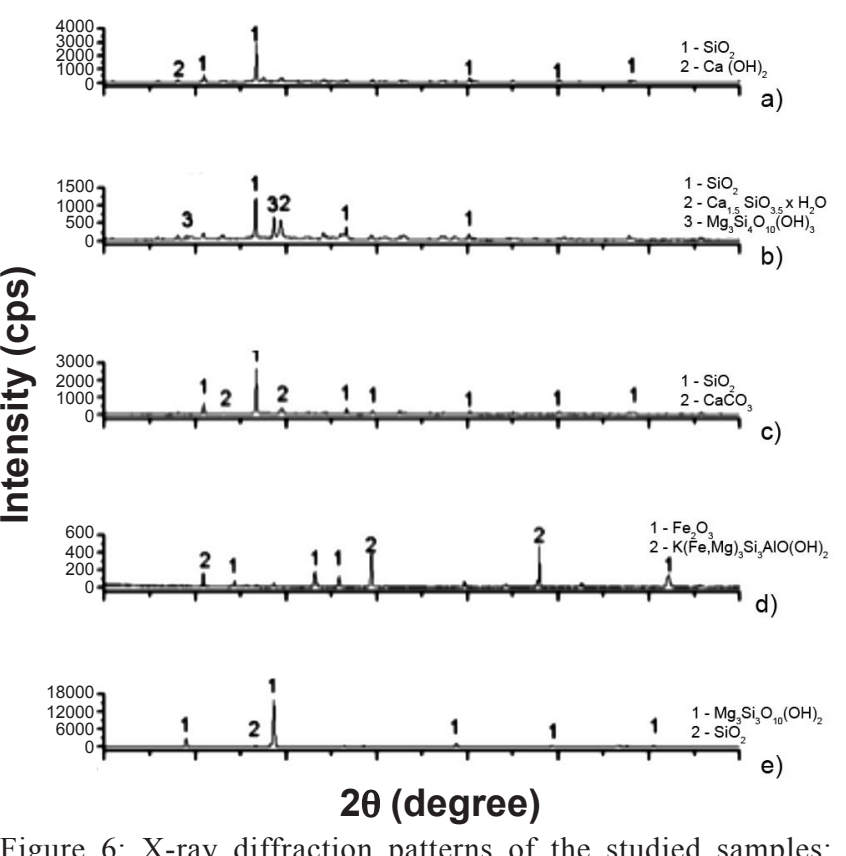

Figure 6: X-ray diffraction patterns of the studied samples: a) commercial paver; b) concrete+talc; c) concrete + mica; d) mica; e) talc.

[Figura 6: Difratogramas de raios $X$ das amostras estudadas: a) paver comercial; b) concreto+talco; c) concreto+mica; d) mica; e) talco.]

Compressive strength: the results of the compressive strength of the samples showed that composition A (concrete+talc) reached 23.4 MPa $(114.5 \mathrm{kN})$ and composition $\mathrm{B}$ (concrete+mica) reached $28.7 \mathrm{MPa}(140.8 \mathrm{kN})$. According to the Brazilian standard ABNT NBR 9781/13 [10], 
Table III - Energy savings for the studied materials.

[Tabela III - Economia de energia para os materiais estudados.]

\begin{tabular}{ccccc}
\hline Material & $\begin{array}{c}\text { Measured } \\
\text { temperature }(\mathrm{K})\end{array}$ & $\begin{array}{c}\text { Environment } \\
\text { temperature }(\mathrm{K})\end{array}$ & $\begin{array}{c}\text { Energy } \\
\left(\mathrm{W} / \mathrm{m}^{2}\right)\end{array}$ & $\begin{array}{c}\text { Energy saving }(\%) \\
\text { compared to asphalt }\end{array}$ \\
\hline Reference concrete (paver) & 319 & 295 & 587.15 & 4.6 \\
Concrete + mica & 318 & 295 & 579.82 & 5.8 \\
Concrete + talc & 309 & 295 & 516.91 & 16.0 \\
Asphalt & 323 & 295 & 615.63 & 0.0 \\
São Tomé stone & 309 & 295 & 513.57 & 16.6 \\
\hline
\end{tabular}

which regulates the mechanical resistance of concrete pavements, such values are below the recommended level of minimum compressive strength of $35 \mathrm{MPa}$ for light vehicle applications. The best performance was found for the reference concrete, with compressive strength of 37.5 MPa $(183.6 \mathrm{kN})$. However, the other compositions could be used in applications with lower demands such as sidewalks, squares and parks, gardens and recreational areas, whose mechanical demands (compression) are not so high.

Considerations of energy savings: reflective materials have good performance on the hottest days and during the period close to the winter solstice, demanding an increase in energy consumption for heating rooms. Synnefa et al. [15] reported that the energy used for heating the environment is less than that spent for cooling, resulting in a positive balance in net savings for buildings located in hot and temperate regions. This can be explained by the fact that the sunlight trajectory in the winter solstice has a smaller sunlight angle, and the sun's rays pass through a higher layer of the atmosphere, reaching the surface of the land less intensely, as described by [16]. Among the various ways to address a possible decrease in energy consumption is a floor that radiates heat to the environment. Thus, Table III presents the results of heat transfer by radiation to the tested materials obtained from the measurements performed using the thermographic camera and the materials exposed to solar radiation. The highest measured temperatures are reported. The exposure time was $6 \mathrm{~h}$ up to the maximum temperature. When analyzing the energy savings for each material in relation to asphalt, the use of São Tomé stone or reference concrete with the addition of talc generates energy savings of up to $16 \%$.

\section{CONCLUSIONS}

This study aimed to evaluate the thermal performance of different materials for urban paving to reduce the surface temperatures of buildings in addition to the environmental temperature. Considering the satisfactory results of the performance of the new material under study, this paper achieved its goal to innovate and advance the field of materials engineering. The application of materials with reflective properties in paving showed good thermal performance, and this concept, principle, or use may be incorporated into other areas of the construction of buildings and building elements, such as opaque fences, walls and roofs. Materials with whiter pigmentation additives have a broader range of electromagnetic frequencies that are no longer absorbed, especially in the infrared range. The goal of this work was the search for new urban paving material with good thermal properties. After laboratory studies, composition A (concrete+talc) demonstrated better thermal performance than the conventional ones, such as asphalt and reference concrete (commercial paver). This material showed similar thermal performance to São Tomé stone. Because of this, such material could be used in the sidewalks, for example. Thus, concrete+talc can be considered cold material with energy saving of up to $16 \%$ in comparison to asphalt. The next step is to improve its mechanical performance in order to meet the standard specifications.

\section{REFERENCES}

[1] P.A. Mirzaei, F. Haghighat, Build. Environ. 45 (2010) 2192.

[2] O. Buchin, M.-T. Hoelscher, F. Meier, T. Nehls, F. Ziegler, Energ. Build. 114 (2016) 27.

[3] O. Buchin, B. Jänicke, F. Meier, D. Scherer, F. Ziegler, Nat. Hazards Earth Syst. Sci. 16 (2016) 963.

[4] J. Yang, Z.H. Wang, K.E. Kaloush, Renew. Sustain. Energ. Rev. 47 (2015) 830.

[5] E.J. Gago, J. Roldan, R. Pacheco-Torres, J. Ordóñez, Renew. Sustain. Energ. Rev. 25 (2013) 749.

[6] A. Dimoudi, S. Zoras, A. Kantzioura, X. Stogiannou, P. Kosmopoulos, C. Pallas, Sustain. Cities Soc. 13 (2014) 89.

[7] M. Santamouris, Energ. Rev. 103 (2014) 682.

[8] M. Santamouris, Renew. Sustain. Energ. Rev. 26 (2013) 224.

[9] N.L. Alchapar, E.N. Correa, M.A. Cantón, Energ. Build. 69 (2014) 22.

[10] ABNT - Assoc. Brasil. Normas Téc., NRB 9781, "Peças de concreto para pavimentação - especificação e métodos de ensaio", Rio de Janeiro (2013).

[11] ABNT - Assoc. Brasil. Normas Téc., NRB 7211, "Agregados para concreto - especificação", Rio de Janeiro (2005).

[12] R. Papitha, M. Buchi Suresh, D. Das, R. Johnson, J. Ceram. 2013 (2012) 1.

[13] H. Akbari, S.J. Konopacki, Energ. Policy 33, 6 (2005) 721. 
[14] Y.A. Çengel, Transferência de calor e massa: uma abordagem prática, Porto Alegre: AMGH (2012).

[15] A. Synnefa, M. Santamouris, K. Apostolakis, Solar Energ. 8, 4 (2007) 488.
[16] A.B. Frota, Geometria da insolação, S. Paulo: Geros (2004).

(Rec. 01/03/2016, Rev. 27/05/2016, 30/09/2016, Ac. $01 / 10 / 2016)$ 